\title{
THE COLLOCATION IN LEARNING VOCABULARY: THE PROBLEMS AND PEDAGOGICAL SUGGESTIONS
}

\author{
Meylina \\ STMIK Jayanusa Padang \\ Meylin1983@gmail.com
}

\begin{abstract}
This was a descriptive qualitative research which was administered to 20 students of STMIK Jayanusa Padang. The data from the observation shown that the lack of collocation competence of the students noticeable when non-native speakers of English need productive language knowledge. they only experienced the limited number of lexical collocations they know or under the influence of their first language "create" unnatural and farfetched collocations. In order to solve this problem, this investigation aimed to expose the students' collocation problems in vocabulary teaching by using collocation tests and questionnaire. The data found were used to offer some pedagogical suggestions that can be applied in class as a starting point, especially to advanced students. Then it is hoped that students will have properly developed and balanced in learning collocations which will help them speak and write English in a more natural way.
\end{abstract}

Keywords: Collocation competence, lexical collocation, vocabulary learning

(C) 2018Jurnal JILP

\section{KOLOKASI DALAM PEMBELAJARAN KOSAKATA: MASALAH DAN SARAN PEDAGOGIS}

\begin{abstract}
Abstrak
Penelitian ini merupakan penelitian deskriptif kualitatif yang dilaksanakan pada 20 mahasiswa STMIK Jayanusa Padang. Berdasarkan data yang diperoleh dalam observasi, ditemukan kurangnya kompetensi kolokasi dari para mahasiswa sebagai non-penutur asli bahasa Inggris sangat terlihat jelas karena tidak memiliki pengetahuan bahasa yang memadai. Dimana mereka hanya mengetahui jumlah kolokasi leksikal yang terbatas karena bahasa mereka masih dipengaruhi bahasa pertama yang menyebabkan penggunaan kolokasi yang tidak wajar dan tidak masuk akal. Untuk mengatasi masalah ini, penyelidikan ini bertujuan untuk mengekspos masalah kolokasi siswa dalam pengajaran kosa kata dengan menggunakan tes kolokasi dan kuesioner. Data yang ditemukan digunakan untuk menawarkan beberapa saran pedagogis yang dapat diterapkan di kelas sebagai titik awal, terutama untuk siswa tingkat lanjut. Kemudian diharapkan bahwa siswa akan dapat memahami kolokasi dengan benar dan menerapkannya dalam belajar kolokasi yang nantinya akan membantu mereka berbicara dan menulis bahasa Inggris dengan cara yang lebih alami.
\end{abstract}

Keywords: Kompetensi kolokasi, kolokasi leksikal, pembelajaran kosakata

Jurnal JIPS (Jurnal Ilmiah Pendidikan Scholastic) Vol. 2 No. 3 (2018) ISSN : 2579-5449

This work is licensed under a Creative Commons Attribution-NonCommercial 4.0 International License. 


\section{INTRODUCTION}

Learning foreign language becomes an important thing for students nowadays. When they learn it, many think that learning vocabulary is fundamental, but difficult. With the size and the complexity of the English of native speaker's mental lexicon and its relation to EFL syllabus target, knowing how to teach vocabulary effectively in classroom must be desirable and crucial aspect of language learning.

Use the "Insert Citation" button to add citations to this document.

Thus, effective teaching may be based more on the development of skills and practices than on knowledge and content (Bialystok 1985), and help students towards meta-cognitive awareness of strategy choices. As Sternberg (1987) maintained, a main function of teaching vocabulary should be to teach students to teach themselves. Moreover, Morgan and Rinvolucri (1986:5) found out that learners in interviews claimed they used many techniques that are not very commonly used in classrooms. When it comes to language learning, a range of arguments have been put forward to justify giving attention to collocations. In learning another language, it is evident that we have to learn both grammatical correctness and idiomatic preference. Collocations, as shown by corpus studies, constitute an important part of idiomaticity. Pawly and Syder (1983) argue that collocational knowledge, as the essence of language knowledge, is indispensable for language learners to produce fluent and appropriate language. Many words are used in a limited set of collocations or multi-word units, and thus knowing their collocational possibilities should be one essential aspect of language learning.

Although the concept has long been a popular topic in linguistics, there is no universally accepted formal definition of collocation (Lewis 2001; Grant and Bauer 2004), which results in a plethora of different terms such as fixed expression, word-combination, idiom, phrase, and prefabricated pattern. Accordingly, many linguists and researchers tend to classify multi-word units into the following three categories (e.g. Howarth 1998; Lewis 2001; Cowie 1993; Bahns 1993; Nesselhauf 2003;
Grant and Bauer 2004), though the terminology used by them might be slightly different:

1. Free collocations (also referred to as open collocations or free word combinations) consist of items used in their literal senses and freely substitutable, such as open the gate, a nice car. This category seems to include all possible and semantically natural combinations. Notice that saying a collocation is a free one does not mean that there is no restriction at all. The major difference between free collocations and restricted ones is that the restriction for the former is a result of the semantic properties of the two components concerned, whereas the restriction for the latter is "a somewhat arbitrary convention of the language" (Nesselhauf 2003: 225).

2. Restricted collocations (also referred to as fixed combinations or collocations) usually have one item used in a non-literal sense, often a specialized, or figurative sense, and the other used in its normal meaning such as run $a$ company, bitterly contested. A collocation of this category, according to Howarth (1998), might permit limited substitution in either of its constituents as in make/reach a decision and take on an obligation/a duty, or in both components as in do/carry out research/ a project. The vocabulary choice is less predictable in this category of collocations than in the previous one.

3. Idioms are relatively frozen expressions, the meanings of which can barely be derived from the meanings of their constituent parts such as sweeten the pill, kick the bucket. On another dimension, collocations can be divided into two major types depending on the word class of their constituents (Biskup 1992; Lewis 2001)

4. Lexical collocations combine two open class words such as verb + noun (lead a life), adjective + noun (a vague answer).

5. Grammatical collocations combine an open class word and one closed class word (grammatical word) such as preposition + noun (in advance), verb + preposition (engage in), or a grammatical structure such as an infinitive

Jurnal JIPS (Jurnal Ilmiah Pendidikan Scholastic) Vol. 2 No. 3 (2018) ISSN : 2579-5449

This work is licensed under a Creative Commons Attribution-NonCommercial 4.0 International License. 
(opportunity to do something), clause (to be afraid that...).

A native speaker listener will know what make a crime means but commit a crime is standard usage. Learning collocations increases the range of one's English vocabulary, so as to avoid or go beyond words like very or nice by choosing a word that fits the context better and has a more precise meaning. A list of reasons for learning collocations we might present to learners could include (1) your language will be more natural and more easily understood; (2) you will have alternative and richer ways of expressing yourself; and (3) your brain will probably have an easier time processing language in chunks or blocks rather than as single words (O'dell \& McCarthy, 2008).

Teaching vocabulary is a process or a unit of ways to make students learn or acquire vocabulary that is presented by teachers. There are several suggestion related to teaching vocabulary, Doff (1989) suggests some ways of presenting vocabulary. They are as follows: (1) Introduce the words by using media or real object; (2) Say the word clearly and write it on the board; (3) Get the class to repeat the words in chorus; (4) Give an English example to show how the word is used; and the last (5) Ask questions using the new word.

Meanwhile, Finocchiaro (1973) states different ways in teaching English. Namely; teacher should present and practice the vocabulary for active use systematically; vocabulary should always be taught in normal speech utterances; new vocabulary items should always be introduced in known structure; the vocabulary items should be centered about one topic whenever it possible; whenever a familiar word is met in a new circumstance, it should be taught again and practiced; vocabulary items should be taught in the same way we teach everything else; Vocabulary should be practiced as structures are practiced in substitution drill, transformation drill, question, answer, etc; vocabulary items should be reintroduced many times with all the structures and all the situations in which they can logically be used; and, student should be encouraged to learn and use nouns, verbs, adjectives, and adverbs that contain the same roots.

In addition, it is widely accepted that teaching vocabulary should be part of the syllabus and taught in a well-planned and regular basis. Lewis (1993) argues that vocabulary should be at the centre of language teaching due to language consists of grammatical lexis, not lexicalized grammar. In order to develop vocabulary intentionally, explicit teaching is proposed by National Reading Panel (2000) as an effective way. The students should be explicitly taught both specific words and word-learning strategies. In the same way, seeing vocabulary in rich contexts provided by authentic texts, rather than in isolated vocabulary drills, produces robust vocabulary learning. To deepen students' knowledge of words meaning, specific word instruction should be robust (Beck et al., 2002). Rich teaching instruction goes beyond definition knowledge, it gets students actively engaged in using and thinking about word meanings and in creating relationships among words. We must use teaching techniques that can help realise this global concept of what it means to know a lexical item. And we must also go beyond that, giving learner opportunities to use the items learnt and also helping them to use effective written storage systems

There is various way of teaching vocabulary but there is no single 'best' way for teaching vocabulary. It is because every way or technique that use in teaching vocabulary has its own strong points. On the other hand, it also has the weakness. Therefore, the researcher tried to find the problems and choosen a better technique that suits to the students' condition.

\section{RESEARCH METHODS}

This research is a qualitative descriptive research. The subject of the research were 20 students of STMIK Jayanusa Padang which was choosen randomly from various semesters. In the present study, researcher has employed various

methods of collecting data. Some have used native speaker introspection and others have used personal observations cross-checked to a greater extent by native-speakers. The present study entails another approach namely collection of

Jurnal JIPS (Jurnal Ilmiah Pendidikan Scholastic) Vol. 2 No. 3 (2018) ISSN : 2579-5449

This work is licensed under a Creative Commons Attribution-NonCommercial 4.0 International License. 
data by means of collocation test and questionnaire. Twenty participants involved in collecting the data. These involved 9 males and 11 females of differing ages in various semesters. The audio-recorded address forms were jointly transcribed by the researcher. The questionnaire which was administered by some of students of STMIK Jayanusa Padang was given to the participants before and after the treatment to collect information about problems and attitude in learning collocation.

\section{RESULTS AND DISCUSSION}

Many researchers have attempted to analyze collocational errors made by advanced learners in order to demonstrate their difficulties in collocation use. The data obtained through the questionnaire answered individually before and after the treatment were calculated in the following table:

\begin{tabular}{|c|c|c|c|c|}
\multicolumn{5}{|c|}{ Paired Sample Statistics } \\
\hline Pair & Mean & N & $\begin{array}{c}\text { Std. } \\
\text { Deviation }\end{array}$ & $\begin{array}{c}\text { Std. } \\
\text { Error } \\
\text { Mean }\end{array}$ \\
\hline s1 & 3.55 & 20 & .575 & .195 \\
s2 & 2.60 & 20 & .553 & .197 \\
s3 & 3.65 & 20 & 1.137 & .254 \\
s4 & 2.70 & 20 & .695 & .152 \\
s5 & 4.50 & 20 & .410 & .092 \\
s6 & 1.95 & 20 & 1.146 & .256 \\
s7 & 3.40 & 20 & 1.155 & .266 \\
s8 & 3.15 & 20 & .513 & .143 \\
s9 & 3.45 & 20 & 1.276 & .255 \\
s10 & 3.25 & 20 & 1.229 & .260 \\
s11 & 1.75 & 20 & 1.209 & .270 \\
s12 & 3.70 & 20 & 1.051 & .324 \\
s13 & 3.55 & 20 & .526 & .128 \\
s14 & 3.00 & 20 & 1.451 & .330 \\
s15 & 2.65 & 20 & .967 & .216 \\
s16 & 3.10 & 20 & 1.119 & .250 \\
s17 & 2.65 & 20 & 1.137 & .254 \\
s18 & 2.20 & 20 & 1.005 & .235 \\
s19 & 3.55 & 20 & .575 & .196 \\
s20 & 3.45 & 20 & 1.276 & .255 \\
\hline
\end{tabular}

Displayed the standard deviation of the mean score calculated in the data above, the most common problem that advanced learners have with collocation use. It was as observed by Lennon (1996) and others, is that they lack knowledge as to the collocational possibilities of verbs; hence mismatches between lexical items as in stop the fire (put out the fire). A second type of error is blending (Howarth 1998), i.e. to fill in the combinations within overlapping clusters by analogy, hence the wrong use of pay care (blend of pay attention and take care). So far, much attention has been focused on the collocational possibilities of the two lexical items in question.

However, in a study of verb + noun collocations used by a group of German learners of English, Nesselhauf (2003) found that by no means all errors occurring are a mismatch between the verb and the noun. Other types of errors such as prepositional errors as in raise the question about (raise the question of) and determiner errors as in get the permission ( $\mathrm{get}$ permission) are also fairly frequent among

Jurnal JIPS (Jurnal Ilmiah Pendidikan Scholastic) Vol. 2 No. 3 (2018) ISSN : 2579-5449

This work is licensed under a Creative Commons Attribution-NonCommercial 4.0 International License. 
students of STMIK Jayanusa Padang. These types of errors are particularly related to restricted collocations due to their variability. According to Erman and Warren (2000: 52), many collocations allow inflectional variability, which involves the choice of tense, aspect, voice and a determiner (to his/her/our surprise, lay a/the table). However, the variability is not always predictable, but restricted in what seems to be a "non-generalizable manner", which accounts for the above types of collocational errors. Therefore it is not sufficient for advanced learners to know whether lexical items collocate (such as make + decision, have + responsibility). In order to produce acceptable language use, it is essential to know the whole combinations (make a decision, have responsibility for doing something).

In addition, based on the questionnare, the students either use only the limited number of lexical collocations they know or under the influence of their first language "create" unnatural and farfetched collocations. Most intermediate and advanced students of STMIK Jayanusa know such common collocations as have a quarrel, make a decision, and take the responsibility, but few know the similar collocations like pick/provoke/start a quarrel, arrive at/reach/take (BrE) a decision, and assume/bear/shoulder/undertake the responsibility. Collocational familiarity of English learners lags far behind their passive language knowledge. One reason for this is that a large number of 'verb + noun' collocations are "arbitrary and non-predictable". For example one can say: commit a crime and perpetrate a crime, commit a fraud and perpetrate a fraud. However, one can only say commit suicide, not *perpetrate suicide; commit a sin, not *perpetrate a sin. One can say hold a funeral, but not *hold a burial. Likewise, make an estimate is frequently used, but not *make an estimation (Benson, 1986a:258-59). Therefore, the overgeneralization of collocational range is quite risky. In fact, Benson who based his observation on citations from various newspapers and magazines even concluded that "many native speakers of English need help with collocations" (Benson, 1990:27). Thus, from the test results as well as other researchers we can reasonably infer that, since collocational capacity cannot be spontaneously acquired, the teaching of (lexical) collocations is absolutely integral to the encoding of a language by non-native speakers.

Furthermore, even the collocations are listed in the dictionaries, they are often 'hidden' under improper entries so that users can't track them down easily. For example, in the OALD4 users can only find trim one's beard, charge a battery, set a watch under verb entries, not corresponding noun entries. The 1993 edition of the Oxford Dictionary of Phrasal Verbs (ODPV), an innovative dictionary offering many possible "collocates" for particular phrasal verbs, is also difficult to use. This dictionary does, however, have a unique feature-lists of collocates at the head phrase of an entry (i.e. the phrasal verb or longer idiom which the entry defines and illustrates).

\section{Some Pedagogical Suggestions about \\ Lexical Collocations}

Lexical collocations are essential to English learners when they want to speak or write naturally. However, the results of the classroom tests administered to the 20 students of STMIK Jayanusa in collocation competence leave no doubt that they are not acquired by memorizing vocabulary and must be specifically taught. Some suggestions for teaching them are as follows:

(A) A number of typical collocations should be presented from the beginning of second language acquisition. Many kinds of collocations, especially the 'verb + noun' type, can be learned by students with intermediate vocabulary ability, for example: fly a kite, walk a dog, set an alarm, break a code, withdraw an offer, bridge/closelfill a gap, arouse/generate/stir up interest (in), etc. If advanced learners are exposed early enough to large numbers of collocations, vocabulary usage may not become fixed or fossilized in their second language learning.

(B) Emphasis should be placed on lexical collocations with high frequency of cooccurrence rather than on those with figurative uses. Language in use is so flexible and idiosyncratic that not all educated native speakers of English agree with certain judgments of collocability, let alone the metaphorical, imaginative, and creative uses of language which

Jurnal JIPS (Jurnal Ilmiah Pendidikan Scholastic) Vol. 2 No. 3 (2018) ISSN : 2579-5449

This work is licensed under a Creative Commons Attribution-NonCommercial 4.0 International License. 
result in the constant formation of new lexical collocations (Rudzka et al., 1981b:6).

(C) When possible, the teaching of collocations should be simplified by using contrastive analysis of lexical collocations (Bahns, 1993). Those with direct equivalence sometimes do not have to be taught, e.g. lose one's patience, logical/persuasive argument, shake one's confidence, furnish/offer/provide information, etc. However, this guideline can't invariably apply to all lexical collocations that have learners counterparts. The collocation explode the myth, for instance, should be emphasized because it will mislead learners to use break the myth.

\section{CONCLUSION}

Researching the collocation problems and devising exercises. The researcher recognize that the teachers should train students in collocation from the early stages. It is actually very difficult for the students at high-beginning level to tackle the exercises. The researcher devised and draw rules from the co build corpus data.

Nevertheless, the students can notice what natural collocation is from these activities and become conscious about this area. It seems that one big reason why so many advanced EFL learners stay at elementary level for so a long time nearly forever in spite of their eagerness for acquiring English is that they dislike making errors and problems in their production, hence they always write simple sentences in order to avoid making errors and problems. Since this investigation has convinced me that writing creatively is strongly related to solving collocational problems, students should be encouraged and given opportunities to write creatively without caring so much about errors and problems. Teachers can utilize such problems to improve their collocation sense and increase students' interests in collocation. 


\section{Bibliography}

Bialystok, E. 1985. The compatibility of teaching and learning strategies. Applied Linguistics 6/3. Pp. 255- 262.

Beck, et al. 2002. Researching vocabulary through a word knowledge framework. studies in second language acquisition. 19, $17-36$

Bahns, J. 1993. 'Lexical collocations: a contrastive view.' ELT Journal 47:56-63.

Benson, M., Benson, E. and Ilson, R. (1986). Lexicographic Description of English. Amesterdam and Philadelphia: John Benjamins.

Benson, M. 1990. 'Collocations and Generalpurpose Dictionaries.' International Journal of Lexicography 3:23-34.

Biskup, Danuta. 1992. L1 influence on learners' renderings of English collocations: A Polish/German empirical study. In P. J. L. Arnaud and H. Béjoint

(eds.). Vocabulary and applied linguistics, 8593. Basingstoke: Macmillan.

Cowie, A. P. and Mackin, R. 1993. Oxford Dictionary of Phrasal Verbs Oxford: Oxford University Press. (abbrev. as ODPV)

Erman, Britt and Beatrice Warren. 2000. The idiom principle and the open choice principle. Text 20 (1): 29-62.

Finocchiaro. 1973. The Use of Vocabulary learning for students in language education. Cambridge: Cambridge University Press

Grant, Lynn and Laurie Bauer. 2004. Criteria for re-defining idioms: Are we barking up the wrong tree? Applied Linguistics 25 (1): 38 61.

Howarth, Peter. 1998. Phraseology and second language proficiency. Applied Linguistics 19 (1): 24-44.

Lennon, Paul. 1996. Getting 'easy' verbs wrong at the advanced level. IRAL - International
Review of Applied Linguistics in Language Teaching 34 (1):

23-36.

Lewis, Michael. 2001. Language in the lexical approaches. In Michael Lewis (ed.). Teaching collocation: Further developments in the lexical approach, 126-154. London: Language Teaching Publications.

Lewis. 1993. Reading and improving vocabulary for students and children. massachussets: newburry house publishers.

Morgan, John and Rinvolucri, Mario. (1986). Vocabulary, Oxford: Oxford University Press

National reading Panel. 2000. Teaching children to read: an evidence based assessment of the scientific research literature on reading and its implications for reading instruction. Washington: National institute for child health and human development press

Nesselhauf, Nadja. (2003). The use of collocations by advanced learners of English and some implications for teaching. Applied Linguistics 24 (2): 223-242.

O’dell, Felicity \& Michael McCarthy. 2008. English Collocation in Use: Advanced. Cambridge: Cambridge UP

Pawley, Andrew and Frances Hodgetts Syder. 1983. Two puzzles for linguistic theory: Nativelike selection and nativelike fluency. In J. C. Richards and R. W. Schmidt (eds.). Language and communication, 191-225. London: Longman.

Sternberg, R., 1987. Most vocabulary is learned from context. Pp. 89-106, in McKeown, M., and Curtis, M. (Eds.) The Nature of Vocabulary Acquisition, Hillsdale, NJ.:Lawrence Erlbaum.

Jurnal JIPS (Jurnal Ilmiah Pendidikan Scholastic) Vol. 2 No. 3 (2018) ISSN : 2579-5449

This work is licensed under a Creative Commons Attribution-NonCommercial 4.0 International License.. 